\title{
Vitamin D level in Egyptian children with otitis media with effusion
}

\author{
Ahmed Nabil Abdelhamid Ahmed*iD, Ahmed Adly Mohamed, Marwa Mohamed Elbegermy, \\ Mohamed Ali Abdelghafar and Ahmed Abdelmoneim Teaima
}

\begin{abstract}
Background: This prospective case-control study was conducted from June 2018 to October 2019 in a tertiary referral hospital to investigate the correlation between otitis media with effusion (OME) and serum vitamin D level in children. The study population included 50 children with adenotonsillar hypertrophy and OME (group A) who underwent adenotonsillectomy with tympanostomy tubes insertion compared to 50 children free from any medical or surgical disease (control group). Serum 25-hydroxy vitamin D was measured using electrochemiluminescence technique for both groups.

Results: The mean age in group A was $53.4 \pm 9.2$ months whereas in group $B$ (control group) it was $65.0 \pm 13.2$ months $(P<0.001)$. In group $A$, there were $29(58 \%)$ male children and 21 (42\%) female children while in group $B$, there were $27(54 \%)$ male children and $23(46 \%)$ female children $(P=0.689)$. The mean vitamin $D$ level in group A was $16.0 \pm 6.1 \mathrm{ng} / \mathrm{mL}$ with a minimum of $7 \mathrm{ng} / \mathrm{mL}$ and a maximum of $32.10 \mathrm{ng} / \mathrm{mL}$. In group $B$, the mean vitamin D level was $15.7 \pm 5.3 \mathrm{ng} / \mathrm{mL}$ with a minimum of $7.38 \mathrm{ng} / \mathrm{mL}$ and a maximum of $27.90 \mathrm{ng} / \mathrm{mL}$. The statistical analysis showed that there was no significant difference in the level of vitamin $D$ level between both groups $(P=0.770)$.
\end{abstract}

Conclusion: In this study, the mean level of serum vitamin D was low in children suffering from OME with adenotonsillar hypertrophy and in children without any medical or surgical disease; however, there was no statistically significant difference in the mean serum level of vitamin D between both groups. Therefore, a further study on a larger sample is needed.

Keywords: Secretory otitis media, Otitis media with effusion, Serous otitis media, Vitamin D, Tympanostomy tube

\section{Background}

Otitis media with effusion (OME) is an inflammation of the middle ear (ME) with fluid accumulated in the middle ear cleft without any clinical symptoms or signs of acute infection. It is a very common disease in childhood and is considered the main cause of conductive hearing loss in children [1].

The pathogenesis of OME is multifactorial. Upper respiratory tract infection (URTI), local inflammation, and Eustachian tube dysfunction are considered as contributing factors [2].

\footnotetext{
*Correspondence: ahnabilent@gmail.com

Department of Otorhinolaryngology, Faculty of Medicine, Ain Shams University, 6th Nile Valley Street, Hadayek Alkoba, Cairo 11331, Egypt
}

Concerning the treatment of OME, the American clinical practice guidelines have recommended observation for 3 months from the date of diagnosis (since spontaneous resolution is very common in OME) except for children at risk of learning or speech problems as hearing impairment or developmental delay and craniofacial disorders like cleft palate. In these cases, insertion of ventilation tubes (with or without an adenoidectomy) is the preferred procedure. Untreated OME can result in hearing impairment, recurrent acute otitis media (RAOM), vestibular disturbance, poor school achievement, and decreased quality of life for affected children. Less commonly, OME may cause tympanic membrane destruction resulting in tympanic membrane retraction, cholesteatoma formation, 
or even tympanic membrane perforation [3, 4]. Future therapeutic options for OME must target its pathology. Several forms of new therapeutic interventions are under trial [5].

Vitamin D deficiency is a very common disease. Many people all over the world have insufficient vitamin D levels, despite food fortification with vitamin $\mathrm{D}$ and a variety of medical supplementation. Vitamin D is very important for calcium absorption and contributes to the host immune system, modulating both adaptive and innate immunity and regulating the inflammatory response by downregulation of cytokines [6, 7].

Many studies have shown the relation between vitamin D deficiency and middle ear infections. It was concluded that serum vitamin D level was lower in patients with (RAOM) and after vitamin D intake, the number of attacks decreased significantly $[7,8]$.

The aim of this prospective study was to detect whether there is an association between serum level of vitamin D and OME in Egyptian children.

\section{Methods}

\section{Study design}

This prospective case-control study was conducted in the Department of Otorhinolaryngology, Faculty of Medicine, Ain Shams University Specialized Hospitals, from June 2018 to October 2019 after obtaining the approval of the faculty ethics committee.

\section{Study population}

This prospective study included one hundred Egyptian children living in Cairo, Egypt, aged between 2 and 8 years old with no gender restriction. They were divided into two groups according to the presence of OME.

Group A (cases): 50 children with adenotonsillar hypertrophy (ATH) and OME (diagnosed by history, otoscopic examination, complete audiologic evaluation, and serial tympanometry showing flat type B) with no resolution after watchful waiting for at least 3 months without the intake of any medication like steroids. They underwent adenotonsillectomy and ventilation tubes insertion (either unilateral or bilateral). Strict adherence to new clinical practice guidelines (by avoiding routine adenoidectomy in children less than 4 years of age with chronic OME unless a discrete indication exists like nasal obstruction or snoring) was emphasized [3].

Group B (control): 50 children free from any medical or surgical disease who presented to our outpatient clinics for routine hearing checkup. OME was excluded in all children by otoscopy, within normal audiologic evaluation and type A tympanometry.

\section{Exclusion criteria}

- Children with chronic illness that can affect vitamin D levels in the blood such as steroids intake, renal failure, and liver cell failure

- Vitamin D intake during the past month

- Immunodeficiency (congenital or acquired)

- Children with signs or symptoms of sleep disordered breathing or sleepstudy denoting sleep apnea

- History of adenotonsillectomy or ventilation tube insertion

- Signs of vitamin D deficiency like rickets

- Craniofacial malformations like cleft lip or palate and Down syndrome

After obtaining an informed written consent from all participants' parents before being enrolled in this study, we get full medical and surgical history, full ENT examination (pharyngeal, nasal and otoscopic ear examination), audiological assessment (audiometry and tympanometry), and laboratory investigation.

\section{Laboratory investigation}

A venous blood sample $(3 \mathrm{~cm})$ was taken from all participants during obtaining the preoperative routine blood samples 1 week prior to surgical intervention (in group A) and during outpatient clinic visit in group B. Blood samples were left to clot and then centrifuged for $10 \mathrm{~min}$, then serum was taken for analysis of 25-hydroxy $(\mathrm{OH})$ vitamin $\mathrm{D}$ level by Electro chemiluminescence immunoassay (ECLIA) technique.

Vitamin D deficiency was defined as a serum vitamin D level $\leq 20 \mathrm{ng} / \mathrm{ml}$, vitamin D insufficiency as a serum vitamin D level of $21-29 \mathrm{ng} / \mathrm{ml}$, and normal vitamin D when serum level is $\geq 30 \mathrm{ng} / \mathrm{ml}$. Vitamin D serum level below $7 \mathrm{ng} / \mathrm{ml}$ was considered as severe deficiency. Comparison of vitamin D level between both groups was made along with subgroup analysis $[9,10]$.

\section{Statistical methods}

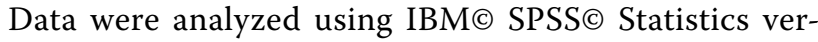
sion 23 (IBM॰ Corp., Armonk, NY). Categorical variables were presented as a number and percentage whereas differences were compared using Pearson chisquared test or Fisher's exact test as appropriate. Continuous numerical variables were presented as mean and SD and inter-group differences were compared using an unpaired $t$-test. Ordinal variables were compared using the chi-squared test for trend. The Bonferroni method was used to adjust the critical $P$-value 
for the number of comparisons. Two-tailed $P$-values $<0.0125$ were considered statistically significant.

\section{Results}

Regarding the OME group, 10 children (20\%) had unilateral OME and underwent adenotonsillectomy with unilateral tympanostomy tube insertion and 40 children (80\%) had bilateral OME and underwent adenotonsillectomy with bilateral tympanostomy tubes insertion. The mean age in the OME group was $53.4 \pm 9.2$ months and in the group B (control group) it was $65.0 \pm 13.2$ months $(P<0.001)$.

In OME group, there were 29 (58 \%) male children and $21(42 \%)$ female children while in the control group, there were $27(54 \%)$ male children and 23 (46\%) female children $(P=0.689)$ (Table 1$)$.

The mean vitamin $\mathrm{D}$ level in the OME group was 16.0 $\pm 6.1 \mathrm{ng} / \mathrm{mL}$ with a minimum of $7 \mathrm{ng} / \mathrm{mL}$ and a maximum of $32.10 \mathrm{ng} / \mathrm{mL}$. In group $\mathrm{B}$, the mean vitamin $\mathrm{D}$ level was $15.7 \pm 5.3 \mathrm{ng} / \mathrm{mL}$ with a minimum of $7.38 \mathrm{ng} /$ $\mathrm{mL}$ and a maximum of $27.90 \mathrm{ng} / \mathrm{mL}$. The statistical analysis showed that there was no significant difference in vitamin $\mathrm{D}$ level between the two groups $(P=0.770)$. Also, subgroup statistical analysis for vitamin D level showed no significant difference between group A and the control group $(P=0.640)$ (Table 2 and Fig. 1$)$.

Analyzing seasonal variation (Table 3 and Figs. 2 and 3) showed that there was no statistically significant difference in serum vitamin D levels between group A and the control group $(P=0.013)$; meanwhile, there was a statistically significant difference in subgroup analysis of the control group $(P=0.004)$ in different seasons. This highlights the importance of serum vitamin D assessment in different seasons due to the significant difference found

Table 1 Demographic characteristics of cases and controls

\begin{tabular}{|c|c|c|c|}
\hline Variable & Cases $(n=50)$ & Controls $(n=50)$ & $P$-value \\
\hline Age (months) & $53.4 \pm 9.2$ & $65.0 \pm 13.2$ & $<0.001^{*}$ \\
\hline Gender & & & $0.689^{\S}$ \\
\hline M & $29(58.0 \%)$ & $27(54.0 \%)$ & \\
\hline F & $21(42.0 \%)$ & $23(46.0 \%)$ & \\
\hline \multicolumn{4}{|l|}{ Surgical intervention } \\
\hline AT & $0(0.0 \%)$ & & \\
\hline $\begin{array}{l}\text { AT with bilateral VT } \\
\text { insertion }\end{array}$ & 40 (80.0\%) & & \\
\hline $\begin{array}{l}\text { AT with unilateral VT } \\
\text { insertion }\end{array}$ & $10(20.0 \%)$ & & \\
\hline
\end{tabular}

Data are mean \pm standard deviation or number (percentage)

AT adenotonsillectomy, VT ventilation tube

* Unpaired $t$-test

${ }^{\S}$ Chi-squared test for trend
Table 2 Serum vitamin D level in cases and controls

\begin{tabular}{llll}
\hline Variable & Cases $(\boldsymbol{n}=\mathbf{5 0})$ & Controls $(\boldsymbol{n}=\mathbf{5 0})$ & $\boldsymbol{P}$-value \\
\hline $\begin{array}{l}\text { Serum vitamin D level (ng/ } \\
\text { ml) }\end{array}$ & $16.0 \pm 6.1$ & $15.7 \pm 5.3$ & $0.770^{*}$ \\
Vitamin D deficiency & $37(74.0 \%)$ & $39(78.0 \%)$ & \\
Vitamin D insufficiency & $12(24.0 \%)$ & $11(22.0 \%)$ & \\
Normal vitamin D level & $1(2.0 \%)$ & $0(0.0 \%)$ & \\
& & & $0.640^{\boldsymbol{n}}$ \\
\hline
\end{tabular}

Data are mean \pm standard deviation or number (percentage)

* Unpaired $t$-test

"Pearson chi-squared test

in vitamin $\mathrm{D}$ in different seasons in children free from any medical or surgical disease.

It is worth noting that mean levels of vitamin D obtained in this study (for cases and control groups) were below normal.

\section{Discussion}

Chronic otitis media with effusion (COME) is an inflammation of the middle ear (ME) space with fluid accumulation in the ME for more than 3 months from the date of diagnosis without clinical symptoms or signs of an acute infection. OME is a very common disease in children and is the main cause of conductive hearing loss in children. The pathogenesis of OME is attributed to many factors including acute otitis media (AOM), local inflammation due to allergy, and Eustachian tube dysfunction [1-3]. In addition to hearing loss, OME is associated in some children with behavioral and learning difficulties [11, 12].

About the treatment of OME, the American clinical practice guidelines recommended observation for 3 months if the child is not at risk of speech, language or learning difficulties. Ventilation tube insertion is recommended if effusion persisted for more than 3 months [3]. The future therapeutic options for the OME depend on pathophysiology of the disease. Several new therapeutic interventions are still under trial [5].

Vitamin D deficiency is a common disease all over the world [13]. The main source for vitamin D is cutaneous synthesis from exposure to sun ultraviolet $B$ rays since the food sources of vitamin D are not adequate for our needs. Many studies have found seasonal variation in serum level of vitamin $D$, with it being lower in winter due to less exposure to sun rays [14-16].

In addition to its anti-inflammatory effect, vitamin $\mathrm{D}$ has a very important role in modulating the immune system through its receptors on most immune cells including circulating monocytes, macrophages, antigen producing cells, and activated T cells [8, 17-19]. 


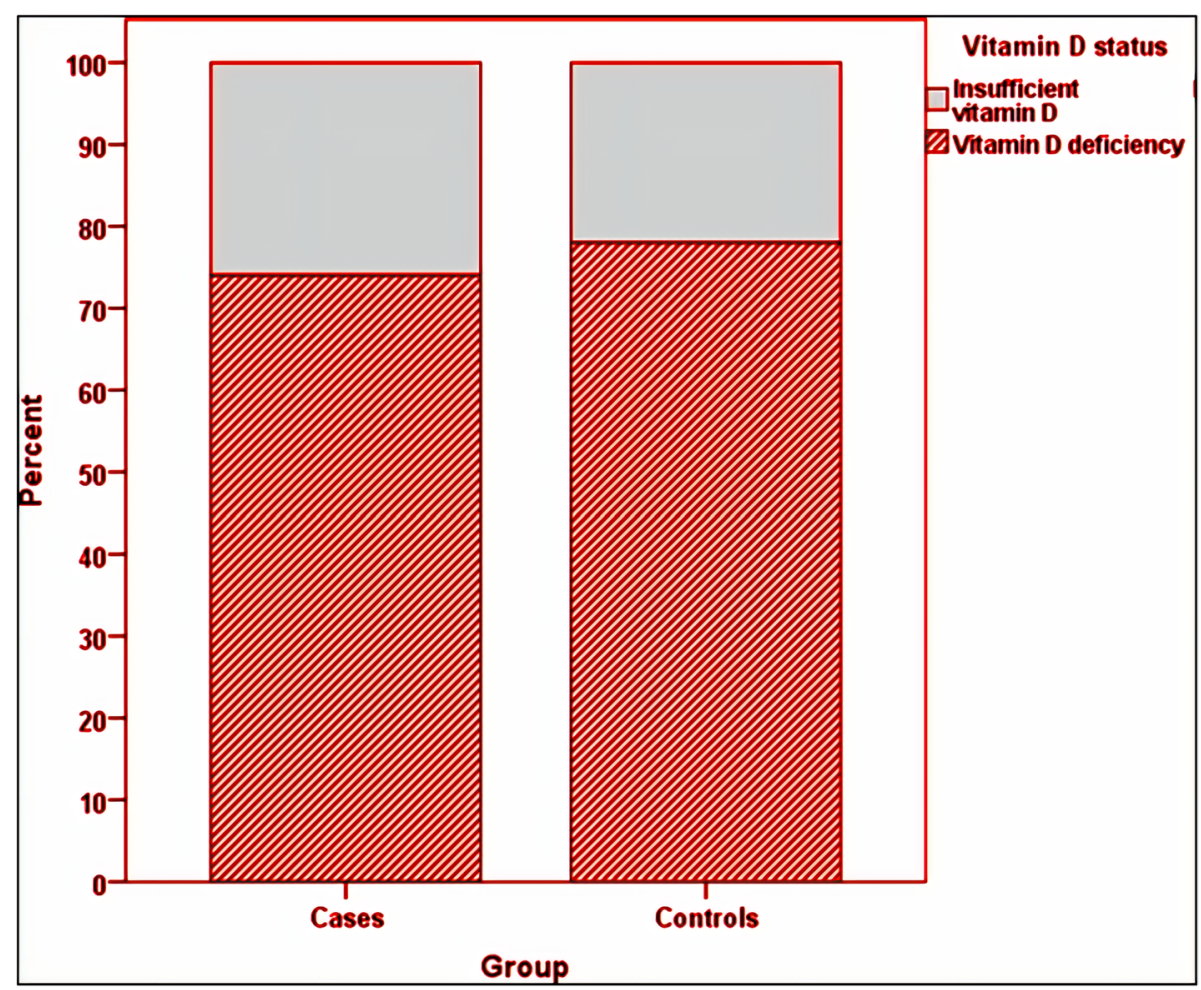

Fig. 1 Vitamin D status in cases and control groups

Table 3 Seasonal differences in vitamin D level in cases and controls

\begin{tabular}{llll}
\hline Group & Season & Serum vitamin D level $(\mathbf{n g} / \mathbf{m l})$ & $\boldsymbol{P}$-value* \\
\hline All study population $(n=100)$ & Autumn and winter $(n=47)$ & $14.6 \pm 5.2$ & 0.013 \\
Cases $(n=50)$ & Spring and summer $(n=53)$ & $17.4 \pm 5.9$ & 0.570 \\
& Autumn and winter $(n=27)$ & $15.5 \pm 6.3$ & $16.5 \pm 5.8$ \\
Controls $(n=50)$ & Spring and summer $(n=23)$ & $13.8 \pm 3.9$ & $\mathbf{0 . 0 0 4}$ \\
& Autumn and winter $(n=20)$ & $18.5 \pm 5.8$ & \\
\hline
\end{tabular}

Data are mean \pm standard deviation

* Unpaired $t$-test

Many studies have demonstrated the correlation between vitamin $\mathrm{D}$ deficiency and the occurrence of respiratory tract and ME infections. Moreover, vitamin D supplementation has decreased the occurrence of AOM, OME, and other upper respiratory tract infections $[20$, 21].

In a case-control study conducted by Cayir et al. in 2014, they found significantly diminished vitamin D levels in patients suffering from recurrent otitis media than the control group. Furthermore, the addition of vitamin D supplementation resulted in lower rates of otitis media recurrence [11].
Sabetta et al. in 2010 have shown that increasing vitamin D above $38 \mathrm{ng} / \mathrm{ml}$ can significantly reduce respiratory tract infections [13]. Also, some studies have indicated a relation between vitamin D deficiency and ATH in children suffering from sleep apnea [22, 23]. Moreover, some studies have shown the correlation between vitamin $\mathrm{D}$ deficiency and recurrent tonsillitis $[24,25]$.

The aim of this study was to investigate the correlation between OME and serum 25- hydroxyvitamin D level in Egyptian children living in Cairo. The study population was confined to Egyptian children because ethnicity and 


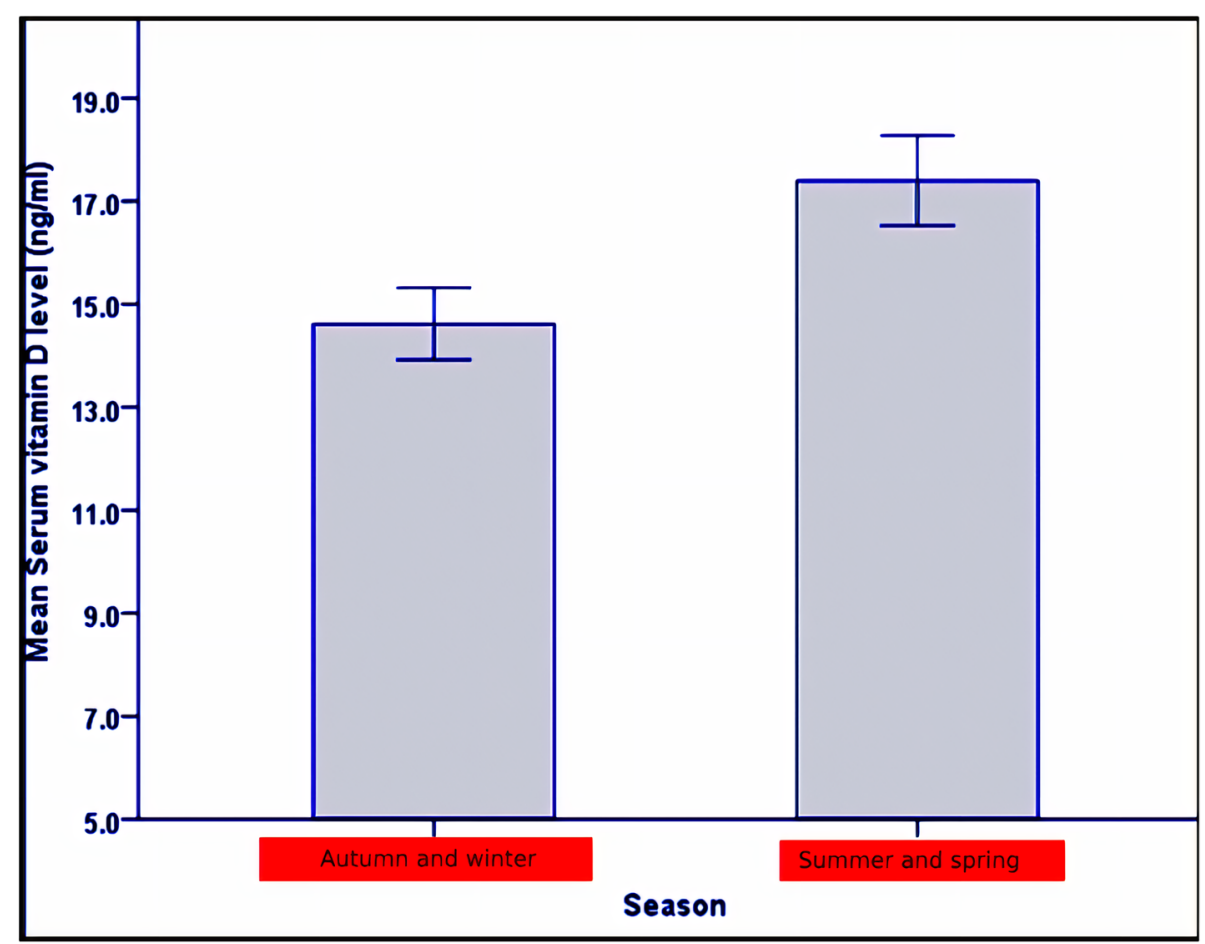

Fig. 2 Mean serum vitamin D level in autumn and winter versus spring and summer in the whole study population. Error bars represent the standard error (SE)

season are very important contributing factors that can affect the serum level of Vitamin D [15].

Serum 25-hydroxyvitamin D level was assessed in 100 children living in Cairo, Egypt, aged between 2 and 8 years old (divided into 2 groups with 50 children in each group). The first group (group A) included children with OME and ATH who underwent adenotonsillectomy and ventilation tube insertion after failed wait-and-see policy for more than 3 months and complete audiologic evaluation with serial tympanometry showing flat type (B) and mean age of $53.4 \pm 9.2$ months, while the second group (control group) included children free from any medical or surgical disease who presented to our outpatient clinics for routine hearing checkup having normal otoscopy, within normal audiologic evaluation and type (A) tympanometry with a mean age of $65.0 \pm 13.2$ months.

The mean level of serum 25-hydroxyvitamin $\mathrm{D}$ in the OME group was $16 \pm 6.1 \mathrm{ng} / \mathrm{mL}$ while in the control group, the mean level of serum vitamin D3 was $15.7 \pm$ $5.3 \mathrm{ng} / \mathrm{mL}$. Although Cairo, Egypt, is a sunny city most of the year, the results of this study showed that the mean level of vitamin $\mathrm{D}$ was below normal in both groups (16 and $15.7 \mathrm{ng} / \mathrm{mL}$ in groups $\mathrm{A}$ and $\mathrm{B}$ respectively); however, there was no statistically significant difference in the mean serum level of vitamin D between both groups. Regarding seasonal variation of vitamin D serum level, there was no statistically significant difference between both groups; however, there was a statistically significant difference within the control group (Table 3). This shows the importance of serum vitamin D measurement in different seasons due to the significant difference found in its level in children free from any medical or surgical disease.

Several other studies have detected an association between vitamin $\mathrm{D}$ deficiency and OME. In a study by Walker et al. in 2017, a higher serum level of vitamin D was linked to lower risk of OME, but one criticism was the inclusion of children of different ethnics that may have affected the results [26]. Also, Akcan et al. in 2018 have revealed a correlation between serum vitamin $\mathrm{D}$ deficiency as well as OME development and prognosis where patients with OME who had complete recovery after wait-and-see policy for 3 months, had a higher serum level of vitamin D than the OME cases with no recovery [27]. A randomized controlled trial by Della Volpe et al. in 2019 found that children who received oral supplements fortified by vitamin $\mathrm{D}$ along with vitamin $\mathrm{E}$, vitamin $\mathrm{C}$, and immune-stimulating molecules had a reduction of upper airway infection episodes and OME [28]. Linda et al. in 2008 found that children who underwent ventilation tube insertion had vitamin $\mathrm{D}$ level less than $20 \mathrm{ng} / \mathrm{mL}$ in $50 \%$ of cases (deficient vitamin D level), 


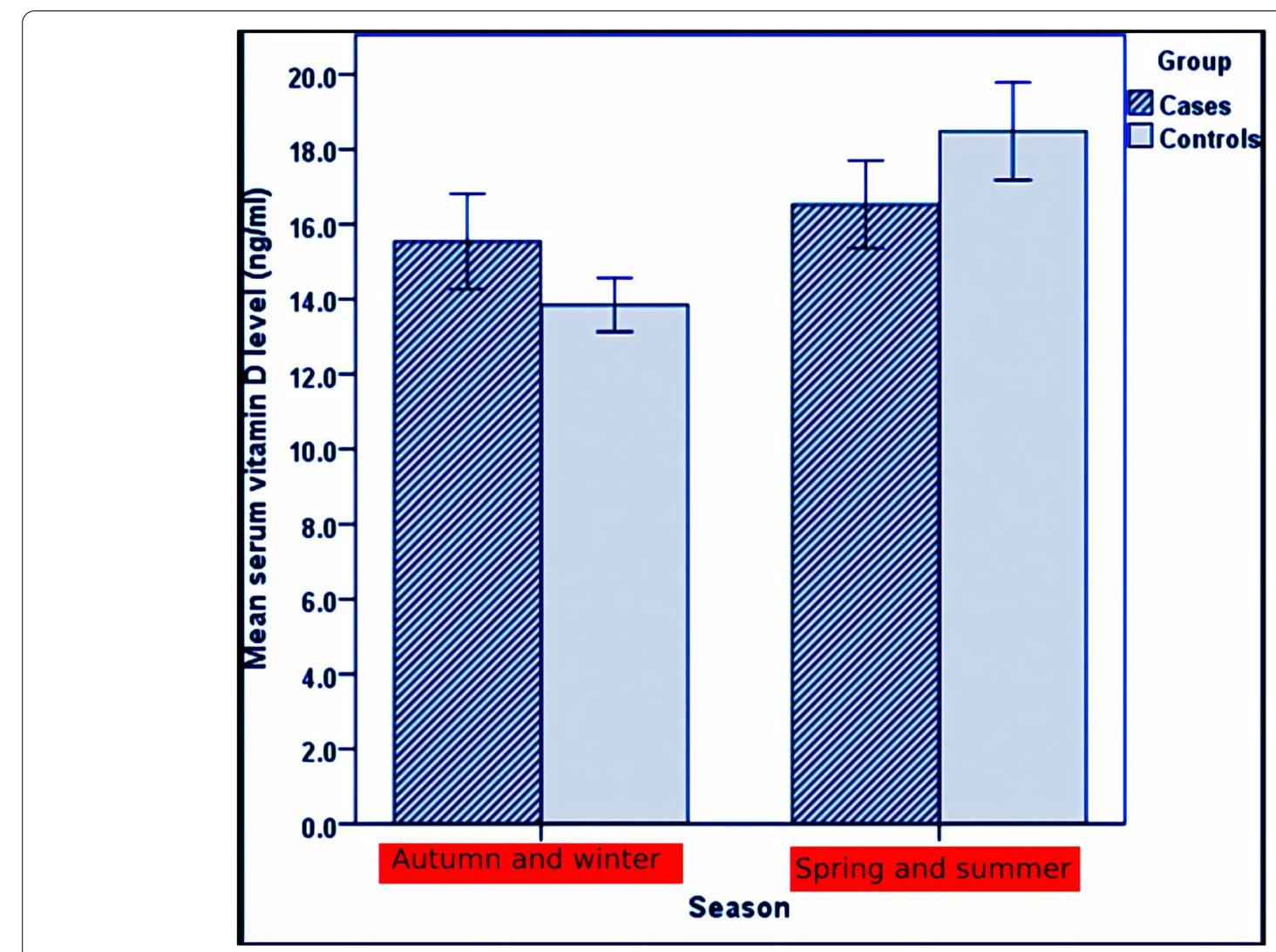

Fig. 3 Mean serum vitamin D level in autumn and winter versus spring and summer in cases and control groups. Error bars represent the standard error (SE)

while $31 \%$ of cases had vitamin D levels between 21 and $29 \mathrm{ng} / \mathrm{mL}$ (insufficient vitamin D level). One limitation of their study was the small number of cases included (16 children only) [29].

Meanwhile, other studies have not found a significant relation between serum level of vitamin D and OME in children. Asghari et al. in 2017 illustrated that no significant differences were found in serum vitamin $D$ in children suffering from adenotonsillar hypertrophy with and without OME [30]. In a meta-analysis and a systematic review study by $\mathrm{Li}$ et al. in 2016 , concerning of the relation between serum 25-hydroxyvitamin D and development of otitis media, five studies were included with pooling of data for 16,689 individuals. Although the results showed a relation between vitamin $\mathrm{D}$ deficiency and the development of recurrent AOM, there was no significant relation between serum vitamin $\mathrm{D}$ deficiency and OME [31].

Although the results of this study showed that there was no statistically significant difference in the mean serum level of vitamin D between children suffering from OME with adenotonsillar hypertrophy and children free from any disease, the relation between vitamin
$\mathrm{D}$ and OME remains controversial, and more studies are needed to show the role of vitamin D deficiency in OME in children.

\section{Limitation of this study}

Small sample groups were included in this study; consequently, it is necessary to conduct further studies with larger sample groups.

\section{Conclusion}

In this study, the mean level of serum vitamin $\mathrm{D}$ was low in children suffering from OME with adenotonsillar hypertrophy and in children free from any medical or surgical disease; however, there was no statistically significant difference in mean serum level of vitamin D between both groups. It is necessary to conduct further studies with larger sample groups.

\section{Acknowledgements \\ Not applicable.}

\section{Authors' contributions}

AN and MA done the study conception and design, acquisition of data,

analysis and interpretation of data, drafting of manuscript and critical revision. AA done the study conception and design, analysis and interpretation of data, 
drafting of manuscript and critical revision. AT and ME done the analysis and interpretation of data, drafting of manuscript and critical revision. All authors have read and approved the manuscript.

\section{Funding}

The authors received no specific funding for this work.

\section{Availability of data and materials}

The data that support the findings of this study are available on request from the corresponding author.

\section{Declarations}

\section{Ethics approval and consent to participate}

The authors declare that this research has been approved by the institutional review board and the ethics committee board of the ENT department, Faculty of medicine, Ain Shams University (Cairo, Egypt). All procedures performed in this study, involving human participants, were in accordance with the ethical standards of the institutional and the national research committee of Egypt and with the 1964 Helsinki declaration and its later amendments (Reference number for the ethical approval was ASUENT19122017). An informed written consent was obtained from all participants' parents or guardians before being involved in this study.

\section{Consent for publication}

Not applicable.

\section{Competing interests}

The authors declare that they have no competing interests.

Received: 21 May 2021 Accepted: 26 November 2021

Published online: 06 January 2022

\section{References}

1. Boudewyns A, Declau F, Van den Ende J, Van Kerschaver E, Dirckx S, Hofkens-Van den Brandt A, Van de Heyning P (2011) Otitis media with effusion: an underestimated cause of hearing loss in infants. Otol Neurotol 32(5):799-804. https://doi.org/10.1097/MAO.0b013e31821b0d07 PubMed PMID: 21593700

2. Minovi A, Dazert S (2014) Diseases of the middle ear in childhood. Laryngorhinootologie. 93(Suppl 1):S1-S23. https://doi.org/10.1055/s-00331363213 Epub 2014 Apr 7. Review. PubMed PMID: 24710778

3. Rosenfeld RM, Shin JJ, Schwartz SR, Coggins R, Gagnon L, Hackell JM, Hoelting D, Hunter LL, Kummer AW, Payne SC, Poe DS, Veling M, Vila PM, Walsh SA, Corrigan MD (2016) Clinical practice guideline: otitis media with effusion (Update). Otolaryngol Head Neck Surg 154(1 Suppl):S1-S41. https://doi.org/10.1177/0194599815623467 PubMed PMID: 26832942

4. Jung TT, Alper CM, Hellstrom SO, Hunter LL, Casselbrant ML, Groth A, Kemaloglu YK, Kim SG, Lim D, Nittrouer S, Park KH, Sabo D, Spratley J (2013) Panel 8: Complications and sequelae. Otolaryngol Head Neck Surg 148(4 Suppl):E122-E143. https://doi.org/10.1177/0194599812467425 PMID: 23536529

5. Atkinson $\mathrm{H}$, Wallis $\mathrm{S}$, Coatesworth AP (2015) Otitis media with effusion. Postgrad Med 127(4):381-385. https://doi.org/10.1080/00325481.2015. 1028317 Review. PubMed PMID: 25913597

6. Esposito S, Lelii M (2015) Vitamin D and respiratory tract infections in childhood. BMC Infect Dis 15:487. https://doi.org/10.1186/s12879-0151196-1 Review. PubMed PMID: 26521023

7. Hewison M (2011) Antibacterial effects of vitamin D. Nat Rev Endocrinol 7(6):337-345. https://doi.org/10.1038/nrendo.2010.226 Epub 2011 Jan 25. Review. PubMed PMID: 21263449

8. Marchisio P, Consonni D, Baggi E, Zampiero A, Bianchini S, Terranova L, Tirelli S, Esposito S, Principi N (2013) Vitamin D supplementation reduces the risk of acute otitis media in otitis-prone children. Pediatr Infect Dis J 32(10):1055-1060. https://doi.org/10.1097//NF.0b013e31829be0b0 PubMed PMID: 23694840

9. Holick MF (2007) Vitamin D deficiency. N Engl J Med 357(3):266-281. https://doi.org/10.1056/NEJMra070553 Review. PubMed PMID: 17634462
10. Ringe JD, Kipshoven C (2012) Vitamin D-insufficiency: an estimate of the situation in Germany. Dermatoendocrinol. 4(1):72-80. https://doi.org/10. 4161/derm.19829 PubMed PMID: 22870356

11. Cayir A, Turan MI, Ozkan O, Cayir Y, Kaya A, Davutoglu S, Ozkan B (2014) Serum vitamin D levels in children with recurrent otitis media. Eur Arch Otorhinolaryngol 271(4):689-693. https://doi.org/10.1007/s00405-0132455-7 Epub 2013 Mar 30. PubMed PMID: 23543299

12. Butler CC, Williams RG (2003) The etiology, pathophysiology, and management of otitis media with effusion. Curr Infect Dis Rep 5(3):205-212. https://doi.org/10.1007/s1 1908-003-0075-x PubMed PMID: 12760817

13. Sabetta JR, DePetrillo P, Cipriani RJ, Smardin J, Burns LA, Landry ML (2010) Serum 25-hydroxyvitamin $d$ and the incidence of acute viral respiratory tract infections in healthy adults. PLoS One 5(6):e11088. https://doi.org/ 10.1371/journal.pone.0011088 PubMed PMID: 20559424

14. Holick MF, Chen TC (2008) Vitamin D deficiency: a worldwide problem with health consequences. Am J Clin Nutr 87(4):1080S-1086S. https://doi. org/10.1093/ajcn/87.4.1080S Review. PubMed PMID: 18400738

15. Schleicher RL, Sternberg MR, Looker AC, Yetley EA, Lacher DA, Sempos CT, Taylor CL, Durazo-Arvizu RA, Maw KL, Chaudhary-Webb M, Johnson CL, Pfeiffer CM (2016) National estimates of serum total 25-hydroxyvitamin $\mathrm{D}$ and metabolite concentrations measured by liquid chromatographytandem mass spectrometry in the US population during 2007-2010. J Nutr 146(5):1051-1061. https://doi.org/10.3945/jn.115.227728 Epub 2016 Apr 6. PubMed PMID: 27052537

16. Klingberg E, Oleröd G, Konar J, Petzold M, Hammarsten O (2015) Seasonal variations in serum 25-hydroxy vitamin D levels in a Swedish cohort. Endocrine. 49(3):800-808. https://doi.org/10.1007/s12020-015-0548-3 Epub 2015 Feb 14. PubMed PMID: 25681052

17. Sassi F, Tamone C, D'Amelio P (2018) Vitamin D: nutrient, hormone, and immunomodulator. Nutrients. 10(11). https://doi.org/10.3390/nu101 11656 Review. PubMed PMID: 30400332

18. Guillot X, Semerano L, Saidenberg-Kermanac'h N, Falgarone G, Boissier MC (2010) Vitamin D and inflammation. Joint Bone Spine 77(6):552-557. https://doi.org/10.1016/j.jbspin.2010.09.018 Epub 2010 Nov 9. Review. PubMed PMID: 21067953

19. Marchisio P, Nazzari E, Torretta S, Esposito S, Principi N (2014) Medical prevention of recurrent acute otitis media: an updated overview. Expert Rev Anti-Infect Ther 12(5):611-620. https://doi.org/10.1586/14787210. 2014.899902 Epub 2014 Mar 28. Review. PubMed PMID: 24678887

20. Jolliffe DA, Griffiths CJ, Martineau AR (2013) Vitamin D in the prevention of acute respiratory infection: systematic review of clinical studies. J Steroid Biochem Mol Biol 136:321-329. https://doi.org/10.1016/j.jsbmb. 2012.11.017 Epub 2012 Dec 7. Review. PubMed PMID: 23220552

21. Bergman P (2017) Can vitamin D supplementation prevent chronic otitis media with effusion? Acta Paediatr 106(9):1385-1386. https://doi.org/10. 1111/apa.13943 PubMed PMID: 28795503

22. Reid D, Morton R, Salkeld L, Bartley J (2011) Vitamin D and tonsil diseasepreliminary observations. Int J Pediatr Otorhinolaryngol 75(2):261-264. https://doi.org/10.1016/j.ijporl.2010.11.012 Epub 2010 Dec 4. PubMed PMID: 21131064

23. Shin JH, Kim BG, Kim BY, Kim SW, Kim SW, Kim H (2018) Is there an association between vitamin D deficiency and adenotonsillar hypertrophy in children with sleep-disordered breathing? BMC Pediatr 18(1):196. https:// doi.org/10.1186/s12887-018-1178-8 PubMed PMID: 29921246

24. Yildiz I, Unuvar E, Zeybek U, Toptas B, Cacina C, Toprak S, Kilic A, Aydin S (2012) The role of vitamin D in children with recurrent tonsillopharyngitis. Ital J Pediatr 38:25. https://doi.org/10.1186/1824-7288-38-25 PubMed PMID: 22682426

25. Aydın S, Aslan I, Yıldız I, Ağaçhan B, Toptaş B, Toprak S, Değer K, Oktay MF, Unüvar E (2011) Vitamin D levels in children with recurrent tonsillitis. Int J Pediatr Otorhinolaryngol 75(3):364-367. https://doi.org/10.1016/j.ijporl. 2010.12.006 Epub 2011 Jan 7. PubMed PMID: 21215466

26. Walker RE, Bartley J, Camargo CA Jr, Flint D, Thompson JMD, Mitchell EA (2017) Higher serum 25(OH)D concentration is associated with lower risk of chronic otitis media with effusion: a case-control study. Acta Paediatr 106(9):1487-1492. https://doi.org/10.1111/apa.13908 Epub 2017 Jun 9. PubMed PMID: 28477429

27. Akcan FA, Dündar Y, Akcan HB, Uluat A, Cebeci D, Sungur MA, Ünlü I (2018) Clinical role of vitamin D in prognosis of otitis media with effusion. Int J Pediatr Otorhinolaryngol 105:1-5. https://doi.org/10.1016/j.jporl. 2017.11.030 Epub 2017 Dec 1. PubMed PMID: 29447793 
28. Della Volpe A, Ricci G, Ralli M, Gambacorta V, De Lucia A, Minni A, Pirozzi C, Paccone M, Pastore V, Di Stadio A (2019) The effects of oral supplements with Sambucus nigra, Zinc, Tyndallized Lactobacillus acidophilus (HA122), Arabinogalactans, vitamin D, vitamin E and vitamin C in otitis media with effusion in children: a randomized controlled trial. Eur Rev Med Pharmacol Sci 23(14):6360-6370. https://doi.org/10.26355/eurrev_ 201907_18460 PubMed PMID: 31364144

29. Linday LA, Shindledecker RD, Dolitsky JN, Chen TC, Holick MF (2008) Plasma 25-hydroxyvitamin D levels in young children undergoing placement of tympanostomy tubes. Ann Otol Rhinol Laryngol 117(10):740744. https://doi.org/10.1177/000348940811701006 PubMed PMID: 18998501

30. Asghari A, Bagheri Z, Jalessi M, Salem MM, Amini E, GhalehBaghi S, Bakhti S (2017) Vitamin D levels in children with adenotonsillar hypertrophy and otitis media with effusion. Iran J Otorhinolaryngol 29(90):29-33 PubMed PMID: 28229060

31. Li HB, Tai XH, Sang YH, Jia JP, Xu ZM, Cui XF, Dai S (2016) Association between vitamin $D$ and development of otitis media: A PRISMAcompliant meta-analysis and systematic review. Medicine (Baltimore) 95(40):e4739. https://doi.org/10.1097/MD.0000000000004739 Review. PubMed PMID: 27749530

\section{Publisher's Note}

Springer Nature remains neutral with regard to jurisdictional claims in published maps and institutional affiliations.

\section{Submit your manuscript to a SpringerOpen ${ }^{\circ}$ journal and benefit from:}

- Convenient online submission

- Rigorous peer review

- Open access: articles freely available online

- High visibility within the field

- Retaining the copyright to your article

Submit your next manuscript at $\gg$ springeropen.com 